\title{
Isatin inhibits the invasion and metastasis of SH-SY5Y neuroblastoma cells in vitro and in vivo
}

\author{
YANAN HUA ${ }^{1}$, NA ZHOU $^{2}$, JINYU ZHANG $^{2}$, ZHENG ZHANG $^{2}$, NING LI $^{2}$, JUN WANG $^{2}$, \\ WENXIANG ZHENG ${ }^{2}$, XUE LI ${ }^{2}$, FANGLING WANG ${ }^{2}$, LI ZHANG $^{3}$ and LIN HOU ${ }^{2}$ \\ ${ }^{1}$ Department of Neurobiology of Basic Experimental Center Medical College, Medical Department, Qingdao University; \\ ${ }^{2}$ Department of Biochemistry and Molecular Biology of Basic Experimental Center Medical College, \\ Medical Department, Qingdao University; ${ }^{3}$ Experimental Center for Undergraduates of Pharmacy, School of Pharmacy, \\ Qingdao University, Qingdao, Shandong 266021, P.R. China
}

Received February 21, 2020; Accepted October 10, 2020

DOI: $10.3892 /$ ijo.2020.5144

\begin{abstract}
Indoline-2,3-dione or indole-1H-2,3-dione, commonly known as isatin, is found in plants of genus Isatin and in Couropita guianancis aubl, and inhibits tumor cell proliferation through its antioxidant effects. The present study analyzed the effect of isatin on the malignant phenotype of neuroblastoma cells, and reported that isatin significantly inhibited neuroblastoma cell proliferation, invasion and migration in vitro in a dose-dependent manner, and distant metastasis in tumor-bearing mice. Mechanistically, isatin inhibited lysine-specific histone demethylase (LSD)1 and reversed the blockade on p53, thereby activating the apoptotic pathway. The inhibitory effect of isatin on LSD1 may be mediated via direct binding and molecular docking or indirectly through the $\mathrm{TGF} \beta / \mathrm{ERK} / \mathrm{NF}-\kappa \mathrm{B}$ signaling pathway. Isatin also alleviated the renal and hepatic toxicity of cyclophosphamide in the tumor-bearing mice, indicating its potential as a candidate drug as well as an adjuvant for treating metastatic neuroblastoma.
\end{abstract}

\section{Introduction}

Isatin is an endogenous indole present in mammalian brain tissues, body fluids, (including urine) and peripheral tissues, as well as in extracts of Brassica oleracea

Correspondence to: Professor Lin Hou, Department of Biochemistry and Molecular Biology of Basic Experimental Center Medical College, Medical Department, Qingdao University, 308 Ningxia Road, Qingdao, Shandong 266011, P.R. China E-mail: qingyi001@126.com

Dr Li Zhang, Experimental Center for Undergraduates of Pharmacy, School of Pharmacy, Qingdao University, 308 Ningxia Road, Qingdao, Shandong 266011, P.R. China

E-mail: zhangli617@126.com

Key words: isatin, neuroblastoma, animal imaging, metastasis, LSD1, antitumor and Indigo naturalis (1). It is the precursor of indirubin, a novel class I anticancer drug, or the isomer of the melanin component involved in oxidative stress (2). However, compared with indirubin, isatin is a smaller molecule with a simpler structure that can overcome steric hindrance and allow penetration into the mucous epithelium (3). In addition, isatin exerts an antioxidant effect via allosteric inhibition of monoamine oxidase inhibitor, indicating its potential as an anticancer agent (4).

Neuroblastoma is the most common extracranial solid tumor diagnosed in infants and children up to 5-years old (5). It originates from the embryonic neural crest cells that normally differentiates into the sympathetic ganglia of the autonomic nervous system, or the catecholamine-secreting cells of the adrenal glands (6). Therefore, neuroblastomas usually arise in the adrenal medulla, neck, chest and spinal cord (6). The clinical manifestations and outcomes of neuroblastoma vary, and patients with localized neuroblastoma have a favorable prognosis and have an disease-free survival rate of $>90 \% 5$ years after diagnosis (7). However, most cases are usually diagnosed when the tumor cells have already metastasized, resulting in a poor prognosis with a 5-year survival rate of $~ 50 \%(8-10)$. At present, patients with high-risk neuroblastoma with early metastasis are treated with high doses of combination chemotherapy (11), which has disadvantages including severe side effects and recurrence.

Plant-derived compounds have gained considerable attention in recent years to treat cancer owing to their minimal toxicity and targeted antitumor effects (12). Isatin is a natural compound (13) and the monomeric precursor of indirubin (14). It is also a constituent of the Daqingye and Qingqing formulations that have a wide range of biological activities (15). Daqingye is widely used for the treatment of influenza, viral pneumonia, mumps, pharyngitis, and hepatitis and has anxiogenic, sedative, anticonvulsant, antineoplastic, antimicrobial and antiviral properties (16).

Lysine-specific demethylase 1 (LSD1), is a flavin-dependent demethylase. It is abnormally overexpressed in a range of solid tumors, particularly in neuroblastoma (17). LSD1 is an established oncogene that promotes metastasis in various cancer types, for example breast cancer, prostate cancer and 
acute myeloid leukemia (18-20) via epigenetic regulation of various pro-oncogenic and pro-angiogenic pathways.

The present study analyzed the effect of isatin on the malignant phenotype of neuroblastoma cells, and the findings indicated that isatin is a promising therapeutic agent against neuroblastoma through LSD1.

\section{Materials and methods}

Cell culture. SH-SY5Y neuroblastoma cells were purchased from American Type Culture Collection, and STR profiling was conducted. The cells cultured in high-glucose DMEM containing 10\% FBS (Gibco; Thermo Fisher Scientific, Inc.) and $100 \mu \mathrm{g} / \mathrm{ml}$ penicillin/streptomycin under $5 \% \mathrm{CO}_{2}$ at $37^{\circ} \mathrm{C}$. The cells were passaged once they were $80-90 \%$ confluent, and logarithmic growth phase cultures were harvested for further analysis.

Cell transfection. The lentiviral construct with the Luc (GV260) tag was synthesized by (Shanghai GenePharma Co., Ltd. After 48 h of cell transfection, the $70-80 \%$ confluent cells were infected with the virus at the MOI of 30 . The stably transduced cells were screened $48 \mathrm{~h}$ later using puromycin, and tested for Luc tag using D-luciferin.

RNA extraction and quantitative $(q) P C R$. RNA was isolated from the isatin-treated cells using the TRIzol ${ }^{\circledR}$ reagent (Invitrogen; Thermo Fisher Scientific, Inc.) according to the manufacturer's instructions, and analyzed using spectrophotometry (BioTek Instruments, Inc.). Following reverse transcription (using a Prime-Script qPCR kit; TransGen Biotech Co., Ltd.), the cDNA was amplified using TransStart SYBR Probe qPCR SperMix (TransGen Biotech Co., Ltd.) on a Bio-Rad One-Step Plus system (Bio-Rad Laboratories, Inc.). The temperature protocol for reverse transcription was $42^{\circ} \mathrm{C}$ for $15 \mathrm{~min}$ and $85^{\circ} \mathrm{C}$ for $5 \mathrm{sec}$. The thermocycling conditions for qPCR were $94^{\circ} \mathrm{C}$ for $30 \mathrm{sec}, 94^{\circ} \mathrm{C}$ for $5 \mathrm{sec}$ and $60^{\circ} \mathrm{C}$ for $30 \mathrm{sec}$, for 45 cycles. Primer sequences for GAPDH, lysine-specific histone demethylase (LSD)1 and p53 are provided in (Table SI). Relative gene expression levels were calculated using the $2^{-\Delta \Delta C q}$ method (21).

Cell Counting Kit (CCK)- 8 assay. Cells in the logarithmic growth phase were washed twice with PBS, harvested using trypsin, and seeded in a 96-well plate at the density of 3,000 cells $/ 100 \mu \mathrm{l} /$ well. After treating with different concentrations $(0,25,50,100,200,300,400,500$ and $800 \mu \mathrm{mol} / \mathrm{l})$ of isatin for 3 days at $37^{\circ} \mathrm{C}$, the cells were washed and incubated at $37^{\circ} \mathrm{C}$ for $1 \mathrm{~h}$ with $10 \mu \mathrm{lCCK} 8$ according to the manufacturer's protocols (Beijing Solarbio Science \& Technology Co., Ltd.). Absorbance was measured at $450 \mathrm{~nm}$ using a microplate reader (Synergy H1; BioTek Instruments, Inc). Each experiment was performed three times.

Cell cloning assay. The cells treated with isatin were seeded in a six-well plate at a density of 100 cells per well and cultured for 2 weeks. The ensuing colonies were fixed with $4 \%$ paraformaldehyde, stained with crystal violet (both at room temperature), air dried and counted manually under a light microscope at $\mathrm{x} 200$.
Apoptosis assay. Cells were seeded in six-well plates at the density of $3 \times 10^{5}$ cells per well, and cultured until $80 \%$ confluent. The cells were harvested and stained using the FITC/PI Annexin V Apoptosis Detection kit I (BD Pharmingen; BD Biosciences) to detect the level of apoptosis using a Accuri C6 flow cytometer and analyzed with the corresponding software (BD Biosciences). The percentage of early apoptotic cells was analyzed using flow cytometry within $1 \mathrm{~h}$ of staining.

Wound scratch assay. The cells treated with isatin were seeded in a 6-well plate and cultured until a uniform monolayer had formed. The layer was scratched with a sterile P200 pipette tip, and the wells were rinsed with the aforementioned medium to remove all cellular debris. Low-serum DMEM with mitomycin $(2 \mu \mathrm{g} / \mathrm{ml})$ was then added to inhibit cell proliferation. Images (Nikon, TI-SM) of the wound area were captured using a TI-SM light microscope (magnification, x100 or x200) at 0,24 and $48 \mathrm{~h}$ post scratching, and the migration rate (\%) was calculated as the percentage of area covered by migrated cells divided by the total wound area.

Transwell assays. Precoating with Matrigel was conducted at $37^{\circ} \mathrm{C}$ for $4 \mathrm{~h}$. The upper compartment of Transwell inserts were seeded with cells in serum-free medium, and the lower chambers were filled with $600 \mu$ l complete medium with $30 \%$ FBS. After 12 to $24 \mathrm{~h}$ of incubation, the inserts were removed, and the cells remaining on the filter surface were swabbed. The cells that had migrated/invaded to the other side the filter were fixed with paraformaldehyde for $5 \mathrm{~min}$ at room temperature), stained with crystal violet and images were captured using a light microscope (magnification, x100).

Western blotting. The cells treated with isatin were lysed in RIPA buffer (Beijing Solarbio Science \& Technology Co., Ltd.) supplemented with a protease inhibitor cocktail (Sigma-Aldrich; Merck KGaA) on ice for $30 \mathrm{~min}$, and centrifuged for $20 \mathrm{~min}$ at $4^{\circ} \mathrm{C}$ and $8,000 \mathrm{x} \mathrm{g}$. The protein concentration in the cleared lysate was measured using a BCA assay (Beyotime Institute of Biotechnology). In total, $20 \mathrm{ng}$ protein were loaded per lane onto a $10 \%$ gel, resolved using SDS-PAGE and transferred to a PVDF membrane. After blocking with 5\% BSA in TBST for $2 \mathrm{~h}$ at room temperature, the membranes were incubated overnight with the primary antibodies (all 1:1,000; Table I) at $4^{\circ} \mathrm{C}$. The blots were washed thrice with TBST, incubated with HRP-conjugated secondary antibody (1:2,000; Wuhan Boster Biological Technology, Ltd.), and washed again with TBST. The protein bands were detected with an ECL detection system (Beijing Transgen Biotech Co., Ltd.). The Fusion FX7 luminescence imaging system (Vilber) was used to visualize and analyze protein bands.

Co-immunoprecipitation. The cells treated with isatin were lysed ( $1 \mathrm{ml} \mathrm{RIPA}$ buffer) at $4^{\circ} \mathrm{C}$ for $30 \mathrm{~min}$, and the lysates were incubated overnight with anti-LSD1 antibody (1:500; Abcam). After adding $40 \mu \mathrm{l} \mathrm{A} / \mathrm{G}$ sepharose (CST, $70024 \mathrm{~S})$, the lysates were incubated for $2 \mathrm{~h}$ at $4^{\circ} \mathrm{C}$ with constant agitation. Cells were centrifuged at 2,000 $\mathrm{x} g$ for $5 \mathrm{~min}$ at $4^{\circ} \mathrm{C}$ and the supernatant was discarded. Cells were washed six times with $500 \mu \mathrm{l}$ wash buffer $(50 \mathrm{Mm}$ Tris- $\mathrm{HCl}$, 
Table I. Antibody information.

\begin{tabular}{ll}
\hline Antibody name & \multicolumn{1}{c}{$\begin{array}{c}\text { Supplier } \\
\text { (catalog number) }\end{array}$} \\
\hline$\beta$-actin & Abcam (ab8226) \\
GAPDH & Abcam (ab8245) \\
LSD1 & Abcam (ab129195) \\
P53 & Abcam (ab26) \\
H3K4Me1 & Abcam (ab176877) \\
H3K4Me2 & Abcam (ab32356) \\
Bax & Abcam (ab32503) \\
Bcl-2 & Abcam (ab59348) \\
MDM2 & Abcam (ab259165) \\
TGF $\beta 1$ & Bioss (bsm-33287M) \\
p-NF- - & Abcam (ab207297) \\
AffiniPure Rabbit Anti-human IgG & Boster (BA1041) \\
AffiniPure Mouse Anti-Rabbit IgG & Boster (BM2020) \\
\hline
\end{tabular}

p-, phosphorylated.

$150 \mathrm{mM} \mathrm{NaCl}, 1 \%$ Triton and 1\% PMSF), then centrifuged at $4,000 \mathrm{x}$ g at $4^{\circ} \mathrm{C}$ for $5 \mathrm{~min}$ and the resulting supernatant was discarded. The immunoprecipitates were separated using SDS-PAGE as aforementioned after washing with the same buffer, and analyzed by immunoblotting with the suitable antibodies.

Cell chemiluminescence detection. After cells were transfected with luc-labelled lentivirus for $48 \mathrm{~h}$, cells in the logarithmic growth phase were plated into a 96-well plate with 2,000 cells/well. After $24 \mathrm{~h}$, the original culture medium was removed and D-luciferin sodium working solution was added $(150 \mu \mathrm{g} / \mathrm{ml})$ with $100 \mu \mathrm{l}$ per well. D-fluorescein sodium working solution was diluted to 1:200 using D-fluorescein sodium stock solution $(30 \mathrm{mg} / \mathrm{ml})$ and pre-warmed culture medium. Within 10-20 min, a microplate reader was used to detect luminescence.

Establishment of in vivo tumor model and treatment. In total, 20 4-week old female athymic nude mice (14-15 g) were purchased from the Vital River Laboratory Animal Technology Co. Ltd. The mice were anesthetized via inhalation of $2 \%$ isoflurane, and inoculated with $1 \times 10^{6}$ tumor cells in $100 \mu 1$ medium between the second and third ribs. The inoculated mice were placed in a $37^{\circ} \mathrm{C}$ incubator until they became fully awake. On day 3 post-injection, the mice were randomly divided into the (A) control, (B) cyclophosphamide (CTX), (C) isatin (ISA) and (D) combination (D) groups $(\mathrm{n}=5$ each), and treated with $5 \mathrm{ml} / \mathrm{kg} 1.25 \%$ Gummi Tragacanthae, $40 \mathrm{mg} / \mathrm{kg}$ CTX, $200 \mathrm{mg} / \mathrm{kg}$ ISA and $20 \mathrm{mg} / \mathrm{kg}$ CTX $+200 \mathrm{mg} / \mathrm{kg}$ ISA, respectively. The drugs were administered daily via the intragastric route for 4 weeks. Tumor formation and metastasis were observed using a live imager. All experimental procedures were performed in compliance with the National Institutes of Health Guide for Care and Use of Laboratory Animals (22), and were approved by The
Animal Ethics Committee of Qingdao University [approval no. QDU20190506b0200610(031)].

Weights of the mice were checked every three days, and fur gloss and behavior were also examined. After 3 days of modeling, the drug was continuously administered for 4 weeks, and mice were imaged in vivo. According to the results, it was found that the tumor metastasis of the mice in the control group had reached the standard, so the mice were sacrificed 4 weeks after drug treatment, and the experiment ended. Animals were euthanized with an overdose of $2 \%$ pentobarbital sodium $(100 \mathrm{mg} / \mathrm{kg})$ followed by cervical dislocation.

Serum marker detection. The following ELISA kits were used to detect specific markers in mouse serum samples: Mouse Matrix metalloproteinase (MMP)2 (cat. no. ZN2705) mouse vascular endothelial growth factor (cat. no. ZN2803), mouse MMP 9 (cat. no. ZN2808), superoxide dismutase (SOD; cat. no. A001-1), glutathione peroxidase (GSH-PX; cat. no. A005), malondialdehyde (MDA; cat. no. A003-1), urea nitrogen (BUN; cat. no. C013-2), creatinine (CREA; cat. no. C011-1), bilirubin (cat. no. C019-1-1), alkaline phosphatase (AKP; cat. no. A059-1) and $\gamma$-GT (cat. no. C017) (all Nanjing Jiancheng Bioengineering Institute). All operations are performed according to the kit instructions.

Molecular docking. Molecular docking was performed using Glide (Schrodinger Inc) with LSD1 crystal structure (PDB Entry: 4KUM) as the receptor. Suitable structural modifications were made, and the water molecules and the crystallized ligand in the protein structure were removed. The refined structure was simulated in an OPLS 2005 force field, and visualized using Maestro in Schrodinger (Schrodinger Suite 2009). The active site was defined as a cubic box containing residues around ligand FAD901 at a distance of $20 \AA$. Other parameters were set at default levels.

Statistical analysis. The data were obtained from at least three independent experiments and analyzed using SPSS 17.0 (SPSS, Inc) for Windows. All data are expressed as mean \pm SD or SEM. ANOVA followed by Tukey's post hoc test was performed to comparing differences between means in multiple groups. $\mathrm{P}<0.05$ was considered to indicate a statistically significant difference.

\section{Results}

Isatin decreases the proliferative activity of SH-SY5Y cells. SH-SY5Y cells treated with 25, 50, 100, 200, 300, 400, 500 and $800 \mu \mathrm{M}$ isatin for 48 and $72 \mathrm{~h}$ showed a marked decrease in proliferation rates (Fig. 1 and Table SII). Concentrations below $200 \mu \mathrm{M}$ did not show any significant effect on cellular morphology, whereas higher doses resulted in aberrant morphological changes, obvious shrinkage and the number of viable cells. Consistent with this, isatin also inhibited clonal expansion of the SH-SY5Y cells in a concentration-dependent manner (Fig. 2). Compared with the untreated control, the number of colonies decreased significantly following treatment with isatin $(\mathrm{P}<0.01)$ (Fig. 2). Similarly, apoptosis rates raised obviously following treatment with 100 and $200 \mu \mathrm{M}$ isatin 


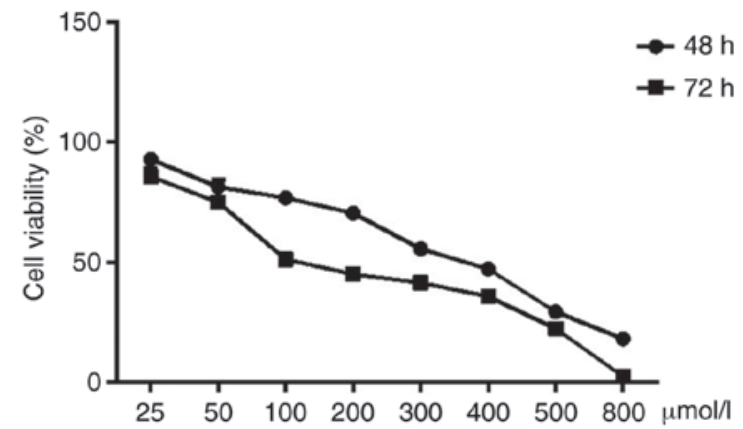

Figure 1. Inhibitory effect of isatin on the viability of SH-SY5Y cells SH-SY5Y cells were treated with different concentrations of isatin for 48 or 72 h. Cell viability was assessed using a Cell Counting Kit-8 assay.

$(\mathrm{P}<0.01)$. Taken together, these data demonstrated that isatin inhibited the proliferation of neuroblastoma cells.

Isatin inhibits the migration and invasion of neuroblastoma cells. The effect of isatin on tumor cell migration and invasion was assessed using wound healing and Transwell assays. The rate of wound healing was significantly slower in the SH-SY5Y cells treated with isatin compared with the untreated cells. At 48 h, wound coverage was almost complete in the control group but a noticeable gap remained in the all isatin-treated groups $(\mathrm{P}<0.01$; Fig. $3 \mathrm{~A}$ and $\mathrm{B})$. Furthermore, isatin also significantly decreased the invasion capacity of the SH-SY5Y cells through the Matrigel-coated Transwell insert (Fig. 3C and D) by 35.22 $\pm 4.21,42.14 \pm 1.58$ and $83.42 \pm 3.67 \%$ at $200 \mu \mathrm{M}(\mathrm{P}<0.01)$, the same level of significance was also observed at 50 and $100 \mu \mathrm{M}(\mathrm{P}<0.01)$.

Molecular mechanisms underlying the antitumor effects of isatin. LSD1 is an oncogene that inhibits the tumor suppressor p53 by demethylating the lysine 370 residue. Consistent with this, LSD1 is overexpressed in neuroblastoma tissues and cell lines, and is associated with the grade of tumor malignancy (17). Isatin significantly decreased the expression of LSD1 mRNA $(\mathrm{P}<0.01,100$ and $200 \mu \mathrm{mol} / 1$ vs. control $)$ and protein $(\mathrm{P}<0.05$, $50 \mu \mathrm{mol} / 1$ vs. control; $\mathrm{P}<0.01,100$ and $200 \mu \mathrm{mol} / 1$ vs. control), and increased that of p53 mRNA ( $\mathrm{P}<0.05,50 \mu \mathrm{mol} / 1 \mathrm{vs.} \mathrm{control;}$ $\mathrm{P}<0.01,100$ and $200 \mu \mathrm{mol} / \mathrm{l}$ vs. control $)$ and protein $(\mathrm{P}<0.01$ vs. control) (Fig. 4A-E). In addition, isatin also upregulated the levels of $\mathrm{p} 53 \mathrm{Me} 2(\mathrm{P}<0.05,50 \mu \mathrm{mol} / 1 \mathrm{vs}$. control; $\mathrm{P}<0.01$, 100 and $200 \mu \mathrm{mol} / 1$ vs. control) (Fig. $4 \mathrm{~F}$ and $\mathrm{G}$ ). Given that LSD1 specifically demethylates histone H3K4 and transcriptionally inhibits the target genes (23), the levels of H3K4Mel and $\mathrm{H} 3 \mathrm{~K} 4 \mathrm{Me} 2$ were also analyzed, demonstrating that isatin treatment significantly upregulated H3k4Me1 $(\mathrm{P}<0.01,100$ and $200 \mu \mathrm{mol} / \mathrm{l}$ vs. control) and H3K4Me2 (P<0.01, 100 and $200 \mu \mathrm{mol} / \mathrm{l}$ vs. control) (Fig. 4H-J). Furthermore, the downstream pro-apoptotic protein p21 was significantly increased by isatin $(\mathrm{P}<0.01 \mathrm{vs}$. control) (Fig. $4 \mathrm{H}$ and $\mathrm{K}$ ) while the p53 destabilizing MDM2 ( $\mathrm{P}<0.05,50 \mu \mathrm{mol} / 1$ vs. control; $\mathrm{P}<0.01$, 100 and $200 \mu \mathrm{mol} / 1$ vs. control) and antiapoptotic Bcl-2 were downregulated ( $\mathrm{P}<0.05$ vs control) (Fig. $4 \mathrm{~L}, \mathrm{M}, \mathrm{O}, \mathrm{P}$ and $\mathrm{R}$ ). TGF $\beta 1$ may activate LSD1 via the ERK/NF- $\kappa$ B pathway (23). Consistent with the aforementioned results, isatin not only decreased the levels of TGF $\beta 1(\mathrm{P}<0.05,50 \mu \mathrm{mol} / 1 \mathrm{vs}$. control; $\mathrm{P}<0.01,100$ and $200 \mu \mathrm{mol} / 1$ vs. control) protein in neuroblastoma cells (Fig. 4Q and S) but also inhibited the co-precipitation of LSD1 and phosphorylated (p-)NF- $\kappa$ B and decreased the expression level of $\mathrm{p}-\mathrm{NF}-\kappa \mathrm{B}$ (Fig. 4T). Taken together, these data demonstrated that isatin inhibits the expression of $\mathrm{TGF} \beta 1 / \mathrm{NF}-\kappa \mathrm{B} / \mathrm{LSD} 1$.

Isatin inhibits the metastasis of neuroblastoma SH-SY5Y cells in nude mice. The Luc-SH-SY5Y cells were injected in nude mice to establish an in vivo neuroblastoma model, and metastasis was tracked using real-time fluorescence imaging. Luc labeling has no direct effect on cell proliferation (Fig. S1). As shown in Fig. 5, the untreated tumor-bearing mice showed strong fluorescence signals in the cervical vertebrae, spine, scapula, pelvic bone and extremities of long bones, indicating that distant metastasis of the tumor cells had occurred. The fluorescence intensities decreased significantly in the ISA and CTX-treated groups, with a more substantial inhibition in the latter $(\mathrm{P}<0.01)$, and were weakest in the CTX+ISA group and limited the brain, spine and pelvis. The CTX dose in the combination regimen was half of that in the monotherapy group, which indicated a synergistic effect of combining CTX and ISA. The nude mice were weighed once every 2 days. No significant changes were found in the body weight of the nude mice in each group (Fig. S2).

A statistical analysis on the fluorescence signal intensity of bone metastasis in each group was made, as shown in Fig. 6A. The results showed that compared with the model group, the fluorescence intensity of bone metastasis in the other three groups was significantly decreased $(\mathrm{P}<0.01$ vs. control; Fig. 6B). Compared with the ISA group, the fluorescence intensity of bone metastases in the CTX group and the combination group was reduced, but there was no statistical difference. There was no significant difference between CTX group and combination group.

The intensity of the transfer fluorescence signal in the main organs of each group of nude mice was analyzed, as shown in Fig. 6C. The results showed that compared with the model group, the fluorescence intensity of the main organs (heart, liver, lung, kidney and spleen) in the other three groups were significantly decreased $(\mathrm{P}<0.01$; Fig. 6D). Compared with the ISA group, the fluorescence intensity of the main organs in the CTX group and the combination group were significantly decreased $(\mathrm{P}<0.01$; Fig. 6D). There was no significant difference between CTX group and combination group. However, no visible solid tumor tissues were found in any of the mice.

The levels of the angiogenic VEGF, and pro-metastatic MMP2 and MMP9 in the sera of the differentially-treated tumor-bearing mice were measured. The expression of VEGF is positively correlated with tumor microvessel density. It can accelerate tumor invasion and early metastasis by promoting tumor angiogenesis to meet the nutrient and oxygen supply needed by rapid growth tumor (24). VEGF levels were significantly decreased in the ISA and ISA+CTX groups compared with the model $(\mathrm{P}<0.01)$ and CTX groups $(\mathrm{P}<0.05)$ (Fig. 7A). MMPs aid tumor cell invasion and metastasis by degrading the extracellular matrix (25), MMP2 decreased significantly in ISA and CTX+ISA group ( $\mathrm{P}<0.01$, vs. control or CTX), simultaneously, MMP9 has obviously decreased in ISA and CTX+ISA group ( $\mathrm{P}<0.01$, vs. control, $\mathrm{P}<0.05$, vs. CTX). Taken 


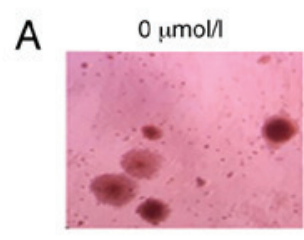

$100 \mu \mathrm{mol} / \mathrm{l}$
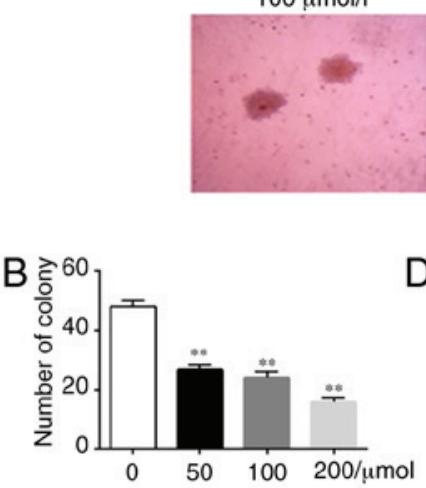

$50 \mu \mathrm{mol} / \mathrm{n}$

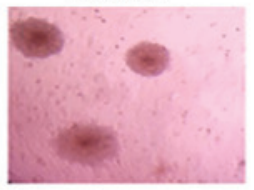

$200 \mu \mathrm{mol} / \mathrm{l}$

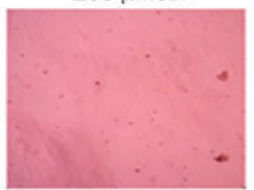

C

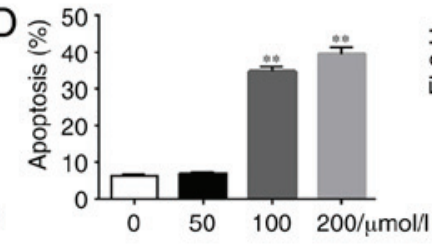

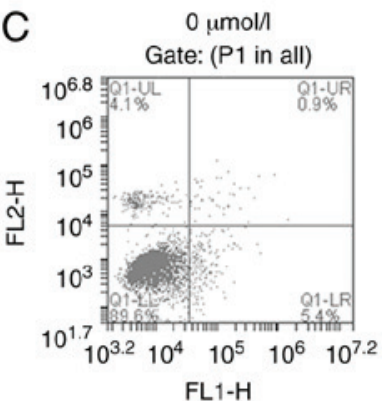

100 umol $/$

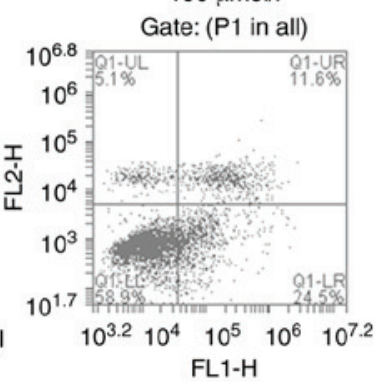

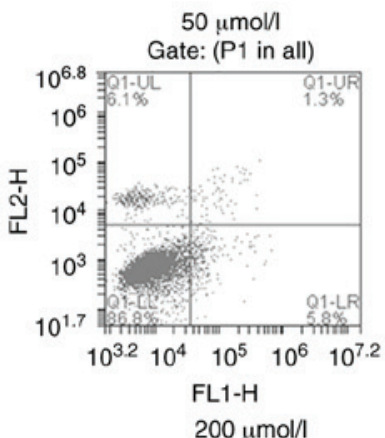

$200 \mu \mathrm{mol} / \mathrm{l}$

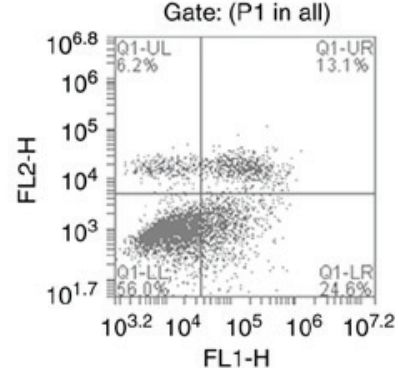

Figure 2. Isatin inhibits the formation of neuroblastoma cells. (A and B) Isatin inhibits anchorage-independent proliferation of SH-SY5Y cells on soft agar. SH-SY5Y cells were treated with different concentrations of isatin. Colony numbers are shown as mean \pm SD from three independent experiments. ${ }^{*} \mathrm{P}<0.01$ isatin vs. control group (C and D) Isatin promotes SH-SY5Y apoptosis. ${ }^{* *} \mathrm{P}<0.01$ isatin vs. control group.
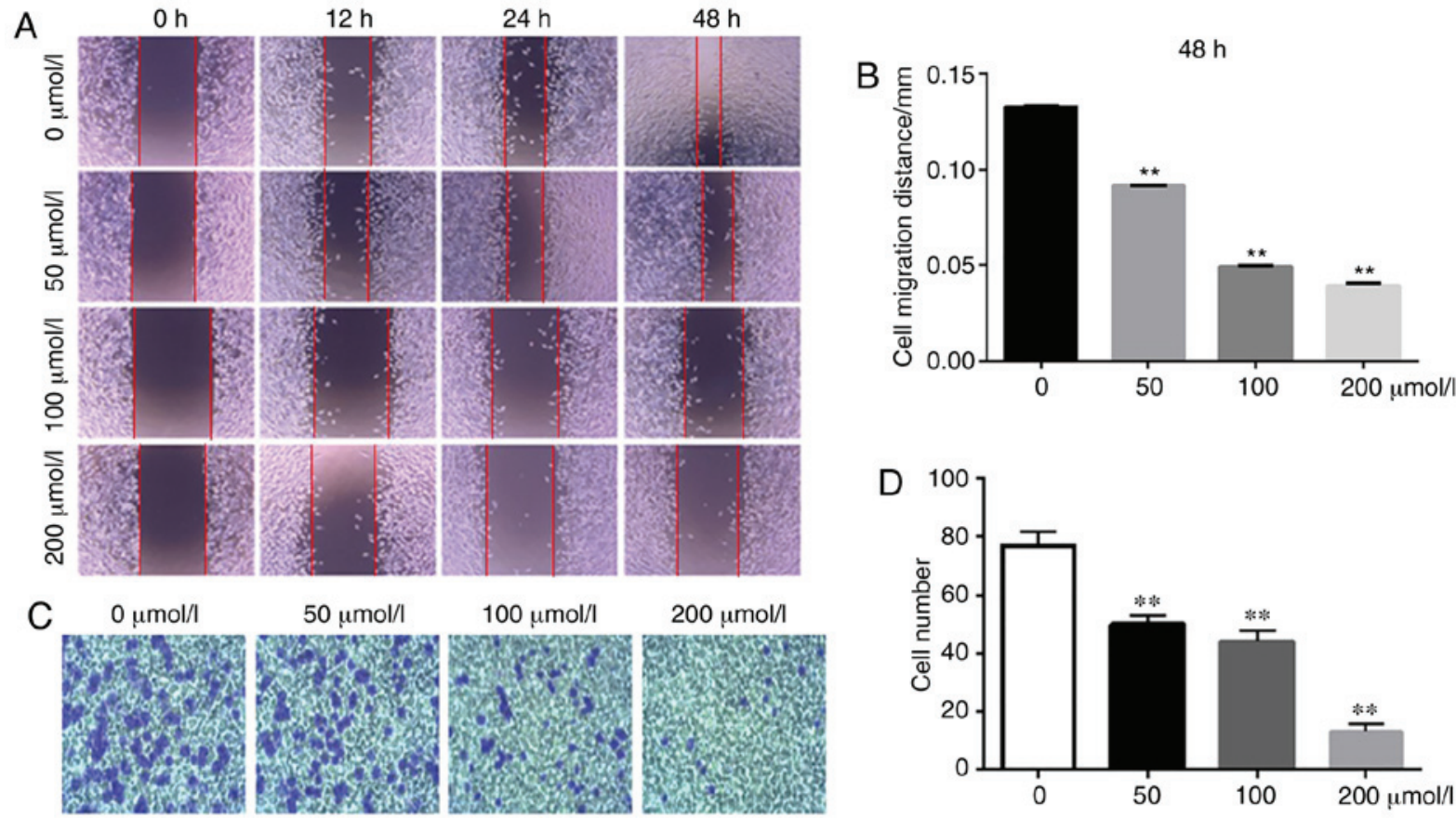

Figure 3. Isatin inhibits the migration and invasion of neuroblastoma cells. (A) Inhibitory effect of isatin on SH-SY5Y cell migration. SH-SY5Y cells wer treated with 50,100 or $200 \mu \mathrm{M}$ isatin for 12, 24 and $48 \mathrm{~h}$. (B) Cell migration distance are shown as mean \pm SD from three independent experiments, ${ }^{* *} \mathrm{P}<0.01$ isatin vs. control group. (C) Inhibitory effect of isatin on SH-SY5Y cell invasion. SH-SY5Y cells were treated with 50, 100 or $200 \mu \mathrm{M}$ isatin. (D) Cell numbers are shown as mean $\pm \mathrm{SD}$ from three independent experiments, ${ }^{* *} \mathrm{P}<0.01$ isatin vs. control group.

together, these data suggested that isatin might inhibit tumor invasion, metastasis and angiogenesis by targeting the MMPs and VEGF.

Effect of drugs on liver and kidney function in animals. The potential adverse effects of ISA were assessed in terms of oxidative stress, renal function and liver function. The results of SOD activity showed that the CTX group was significantly lower compared with the other three groups $(\mathrm{P}<0.05 \mathrm{CTX}+\mathrm{ISA}$ vs. CTX, P $<0.01$ ISA vs. CTX). There was no significant difference in SOD activity between the model, CTX and CTX+ISA groups (Fig. 8A). The activity of GSH-PX enzyme in CTX+ISA group was significantly higher compared with control $(\mathrm{P}<0.01)$, compared with CTX group, GSH-PX activity 

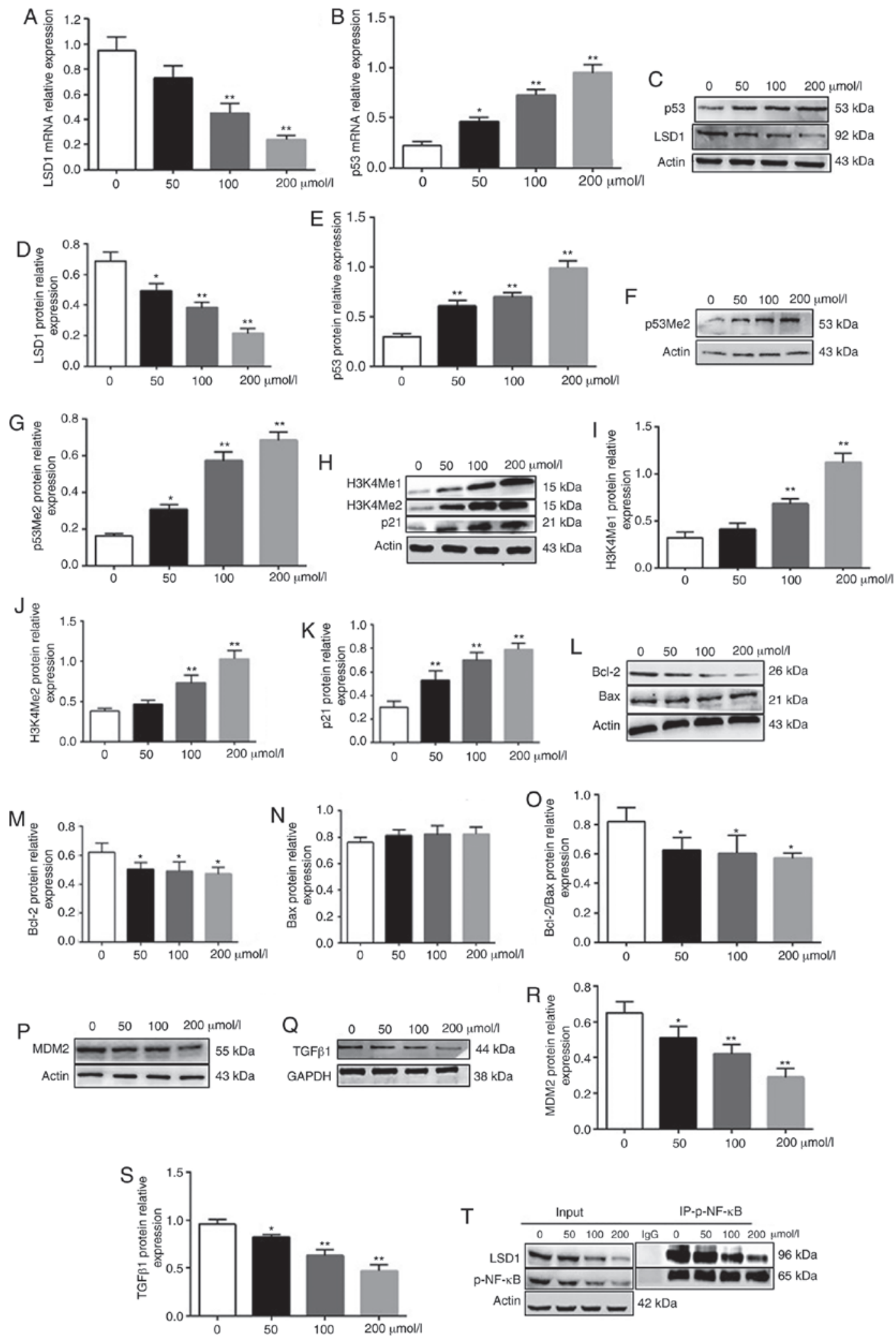

Figure 4. Molecular mechanism underlying isatin action. (A-E) Effect of isatin on the expression levels of LSD1 and p53 mRNA and protein. Relative expression levels are shown as mean values \pm SD from three independent experiments. ( $\mathrm{F}$ and $\mathrm{G})$ Effect of isatin on the expression of p53Me2 protein. (H-S) Effect of isatin on the expression of $\mathrm{H} 3 \mathrm{~K} 4 \mathrm{Me} 1, \mathrm{H} 3 \mathrm{~K} 4 \mathrm{Me} 2, \mathrm{Bcl}-2$, Bax, MDM2 and TGF $\beta 1$ proteins. (T) Co-immunoprecipitation results of LSD1 and p-NF- $\mathrm{B}$ interaction. Results are from three independent experiments and representative images are provided. ${ }^{*} \mathrm{P}<0.05$ and ${ }^{* *} \mathrm{P}<0.01$ vs. control group.

was higher in ISA and CTX+ISA group $(\mathrm{P}<0.01)$ (Fig. 8B). The serum MDA content of the nude mice in CTX group was significantly higher compared with other groups $(\mathrm{P}<0.01$; Fig. 8C).
The BUN content of the CTX group was significantly higher compared with the other three groups $(\mathrm{P}<0.01$ vs. control and CTX+ISA groups, $\mathrm{P}<0.05$ vs. ISA group; Fig. 8D). There was no significant difference in BUN content between 

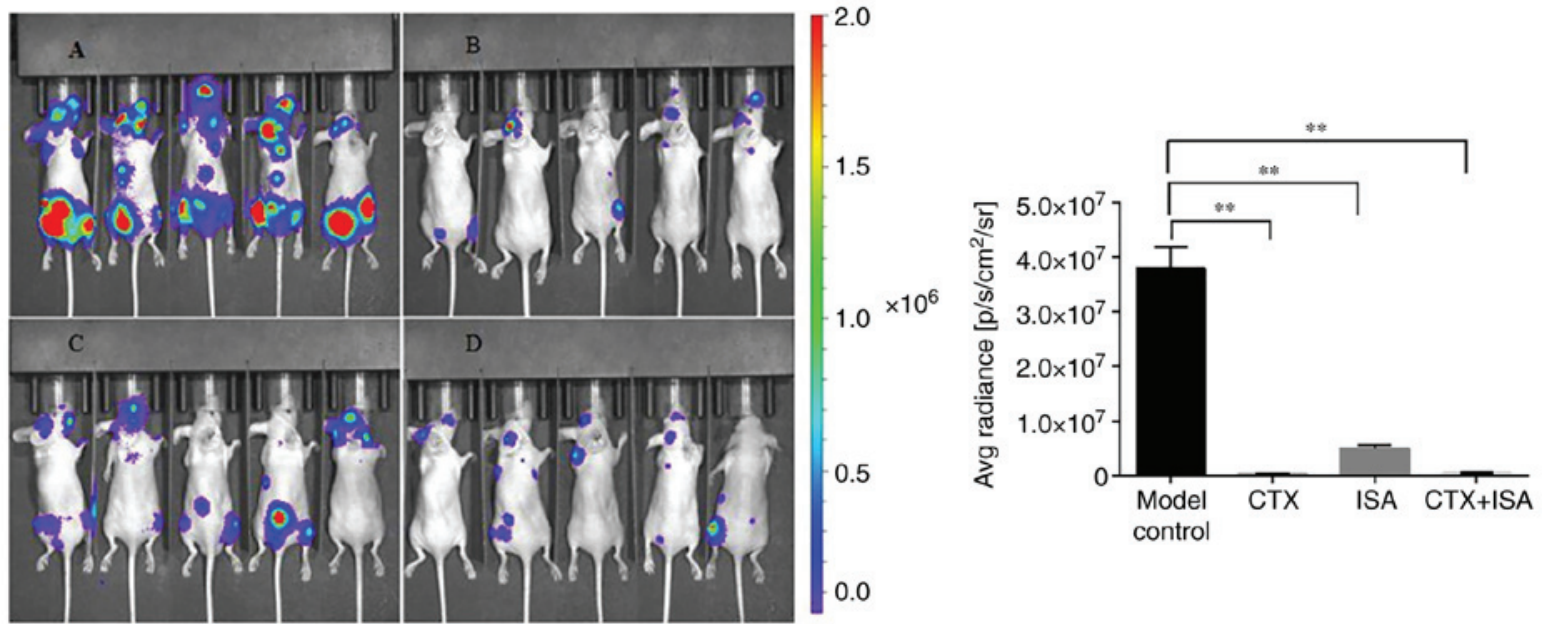

Figure 5. ISA inhibits the metastasis of neuroblastoma SH-SY5Y cells in nude mice. In vivo imaging of metastatic tumors in nude mice after 4 weeks. ${ }^{* *} \mathrm{P}<0.01$ ISA, isatin; CTX, cyclophosphamide; CTX+ISAvs. control group.
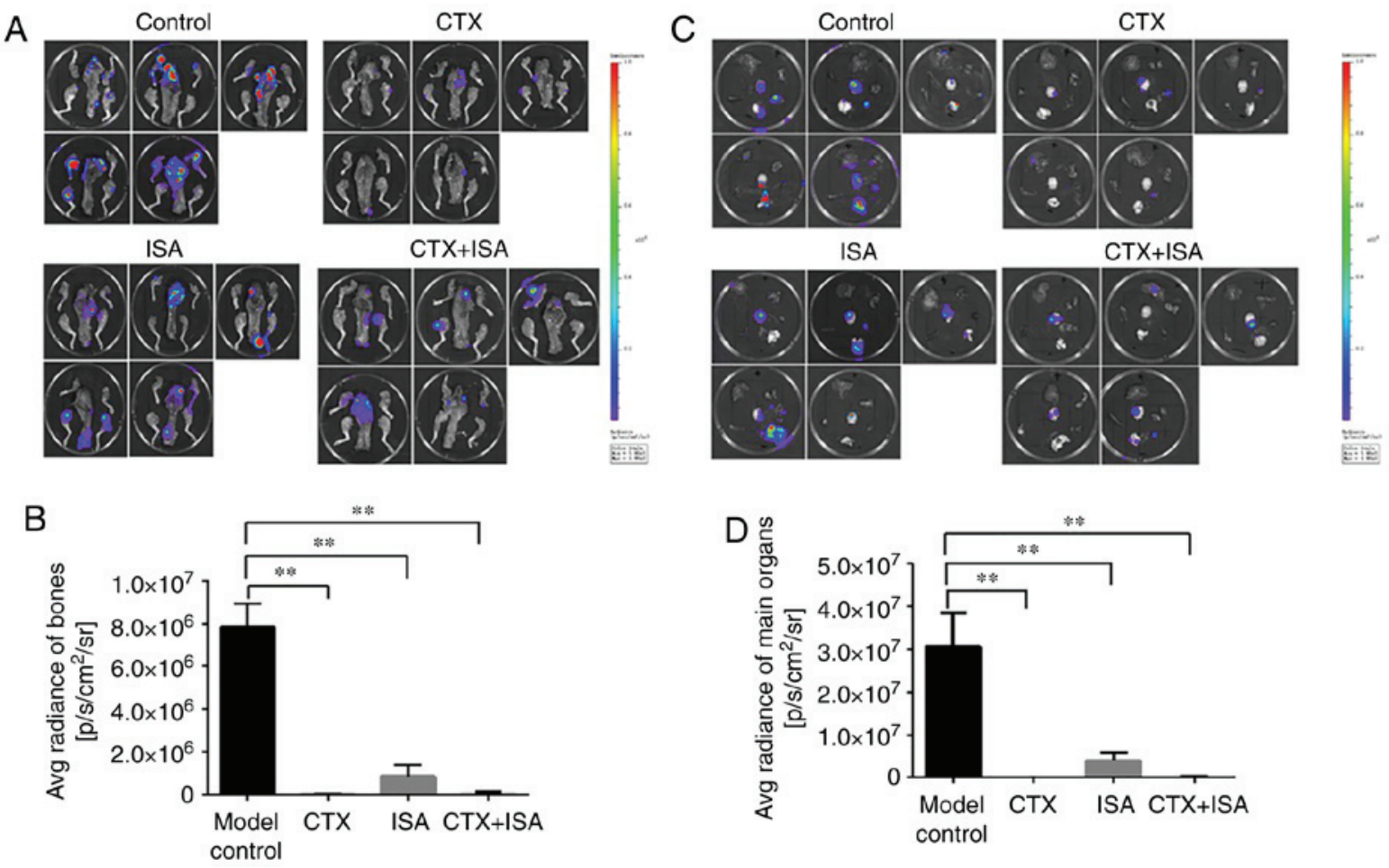

Figure 6. ISA inhibits bone and the main organs (heart, liver, lung, kidney and spleen) metastasis of neuroblastoma SH-SY5Y cells in nude mice. (A) In vivo imaging of bone metastasis in nude mice after 4 weeks. (B) Experimental data are shown as mean \pm SEM (n=5). (C) In vivo imaging of the main organs metastasis in nude mice after 4 weeks. (D) The experimental data are shown as mean \pm SEM $(n=5) .{ }^{* *} \mathrm{P}<0.01, \mathrm{CTX}$, cyclophosphamide; ISA, isatin; and CTX+ISA vs. control group

model and CTX+ISA group (Fig. 8D). The results showed that the concentration of creatinine (CREA) in the CTX group was dignificantly higher compared with other group $(\mathrm{P}<0.05$, vs. control or ISA, $\mathrm{P}<0.01$ vs. CTX+ISA; Fig. $8 \mathrm{E})$. In addition, the concentration of serum bilirubin in the CTX group was significantly higher compared with that in the model group $(\mathrm{P}<0.05)$, and total bilirubin in the ISA and CTX+ISA groups was significantly lower compared with that in the CTX group $(\mathrm{P}<0.05$ and $\mathrm{P}<0.01$, respectively; Fig. 8F). Serum AKP results showed that the AKP activity in the control, ISA and CT+ISA groups was significantly lower compared with that in the
CTX group ( $\mathrm{P}<0.05$ vs. control or ISA, $\mathrm{P}<0.01$, vs.CTX+ISA; Fig. 8G). In addition, the $\gamma$-GT activity of the CTX group was also significantly higher compared with other groups $(\mathrm{P}<0.05$ vs. ISA, P<0.01 vs. control or CTX+ISA; Fig.8H).

Docking results. Since isatin is a monoamine oxidase inhibitor and LSD1 is a monoamine oxidase [Triazole-dithiocarbamate based selective lysine specific demethylase 1 (LSD1) inactivators inhibit gastric cancer cell growth, invasion, and migration, 10.1021/jm401002r], the binding ability was predicted using molecular docking of isatin to the LSD1 crystal structure. As shown in 

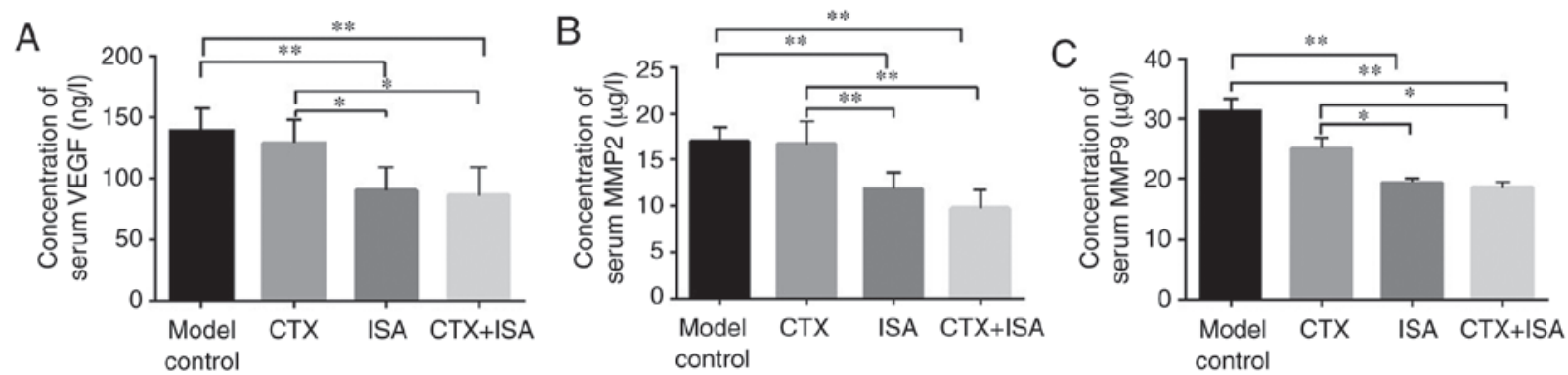

Figure 7. Circulating levels of different tumorigenic factors in the tumor-bearing mice. Effects of ISA on the serum levels (A) VEGF, (B) MMP2 and (C) MMP9. "P<0.05 and ${ }^{* *} \mathrm{P}<0.01$ vs. model control or CTX, cyclophosphamide.

A
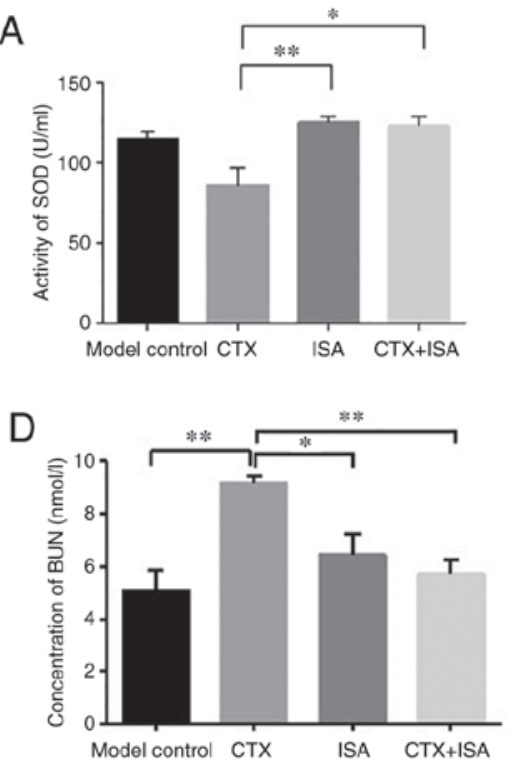

B

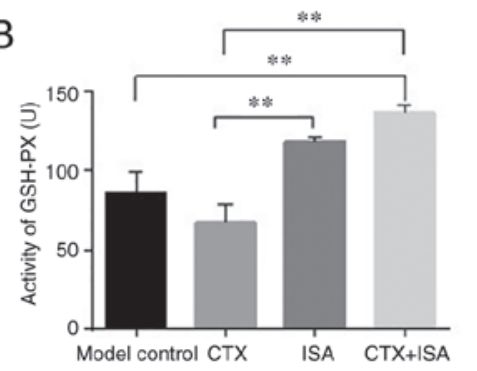

$\mathrm{E}$

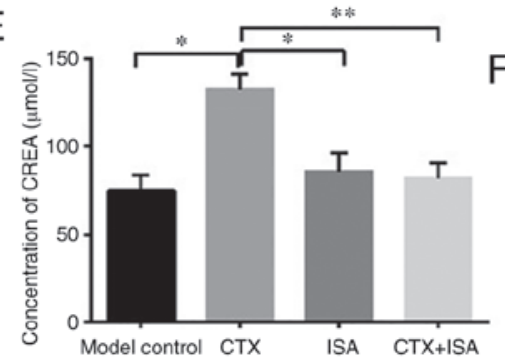

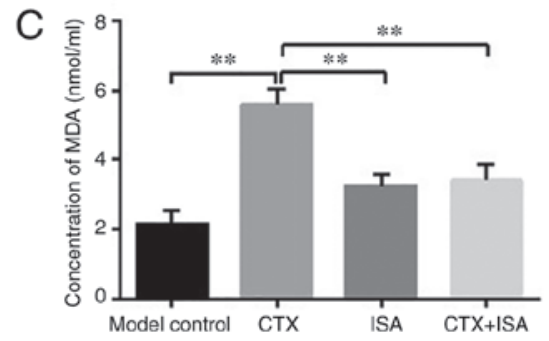

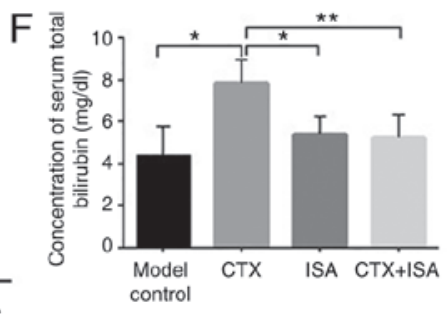

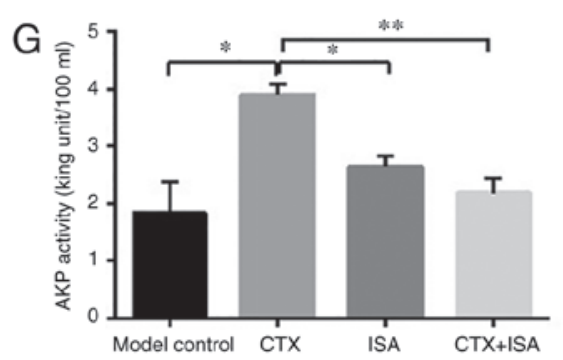

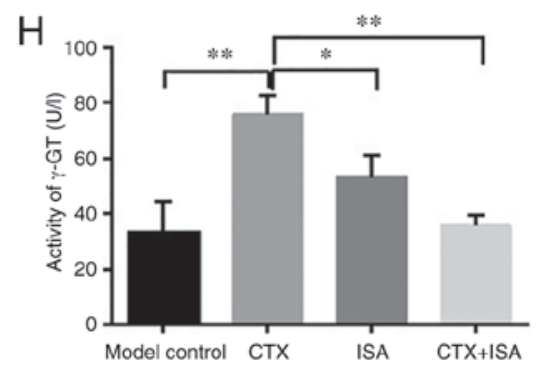

Figure 8. Effect of ISA on liver and kidney function in tumor-bearing mice. Activity of (A) SOD and (B) GSH-PX. Levels of (C) MDA and (D) BUN. (E) CREA activity, (F) bilirubin levels, (G) AKP activity and $(\mathrm{H}) \gamma$-GT activity in the sera of the differentially treated mice. "P<0.05 vs. model control, ISA, CTX or CTX+ISA. ** P<0.01 vs. model control, ISA, CTX or CTX+ISA. CTX, cyclophosphamide; ISA, isatin; SOD, superoxide dismutase; GSH-PX, glutathione peroxidase; MDA, malondialdehyde; BUN, urea nitrogen; CREA, creatinine; AKP, alkaline phosphatase; $\gamma$-GT.

Fig. 9, isatin bound to the surrounding amino acids (colored green) in LSD1 protein via hydrophobic interactions. In addition, electrostatic interactions were also seen at the ligand-receptor binding site (purple amino acids of LSD1). Finally, hydrogen bonds were formed between two carbonyl groups of isatin and the $\mathrm{NH}$ of Glu801 and $\mathrm{OH}$ of Ser289. It was hypothesized that isatin can bind to LSD1 with high affinity and inhibit its function.

\section{Discussion}

Neuroblastoma is one of the most commonly diagnosed pediatric solid tumors (26), and originates from the neuroectodermal tissue that normally develops into the central and peripheral nervous systems (27). In total, $>90 \%$ of cancer-associated deaths in patients with solid tumors are caused by metastases rather than the primary tumor (28). The mortality rates associated with neuroblastoma can also be attributed to its high degree of malignancy and early metastasis, therefore it is important to target the metastatic cells to improve patient prognosis (29). In spite of aggressive chemotherapy and targeted therapy, the prognosis for patients with advanced neuroblastoma remains poor (30). Therefore, the focus of research has shifted to natural compounds that target tumor cells with minimal toxicity to the normal tissues. 

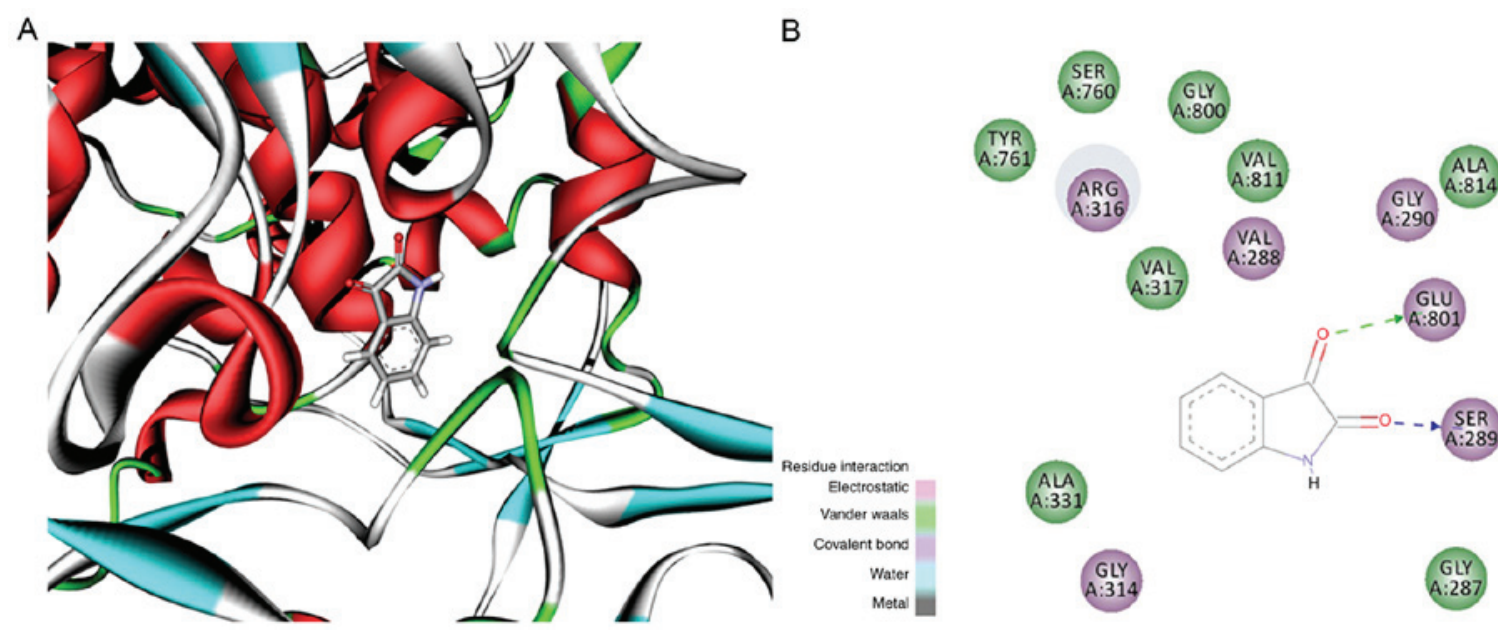

Figure 9. Molecular docking. (A) Three-dimensional structure of isatin and LSD1. (B) Two-dimensional representation of isatin in the active site of LSD1. Green residues, Van der Waals interactions. Purple residues, electrostatic interactions. Dotted lines, H-bond interactions. LSD1, lysine-specific histone demethylase.

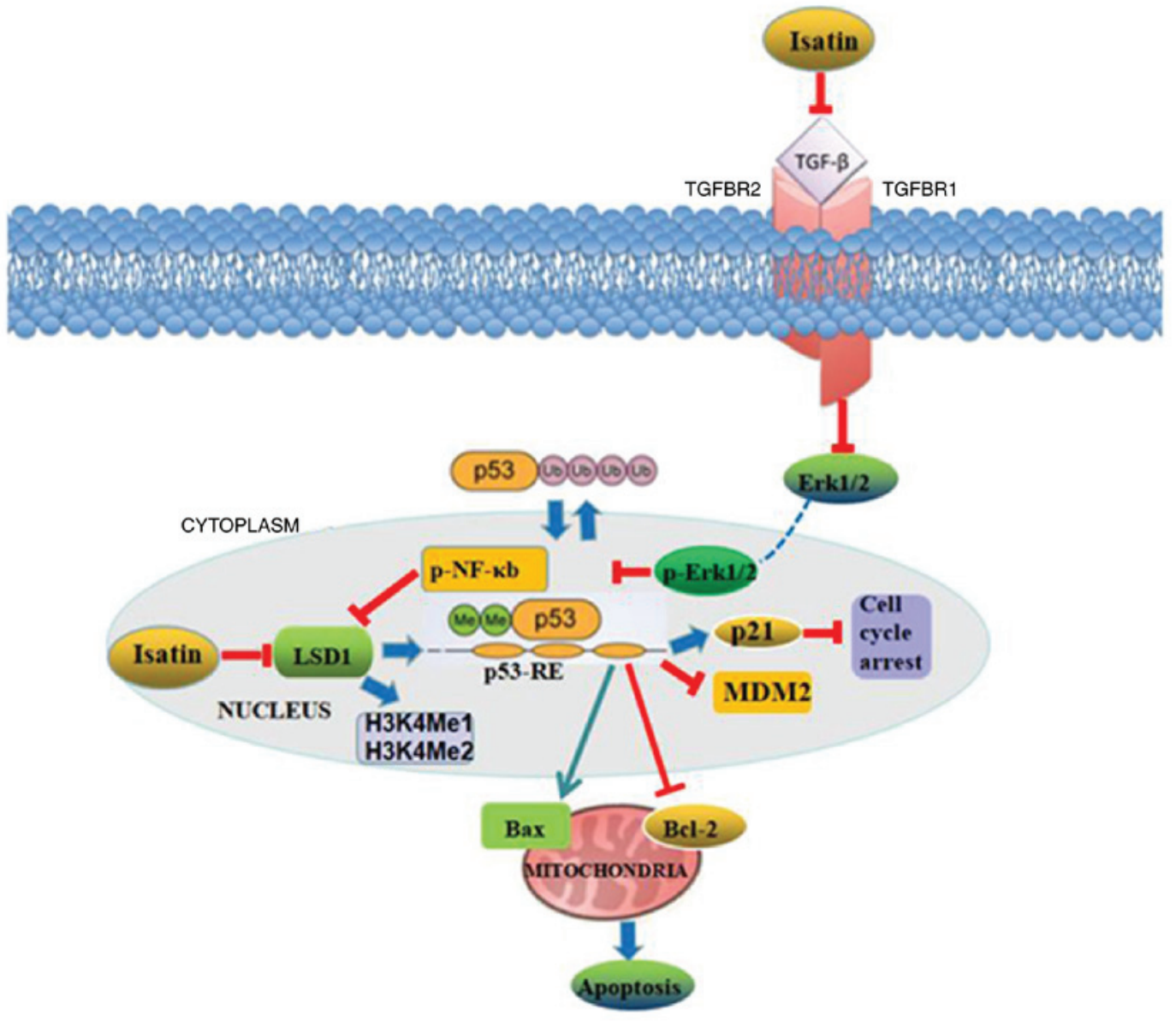

Figure 10. Proposed molecular mechanism of isatin in neuroblastoma. p-, phosphorylated.

The natural compound isatin is a potent antioxidant with neuroprotective and antitumor effects (31), and has the advantages of low molecular weight, oral administration, targeted inhibition of tumor cells and low toxicity (32). Previous studies have shown that isatin increases the apoptosis of neuroblastoma cells in vivo and in vitro $(33,34)$, and inhibits SH-SY5Y cell proliferation and invasion by downregulating MMP-2/MMP-9 and p-STAT3 in a concentration-dependent manner (35).
Furthermore, a previous microarray assay showed that isatin regulates the mTOR-mediated autophagy of SH-SY5Y cells to promote invasion (36). Consistent with this, it was found that isatin inhibits the proliferation, invasion and migration abilities of SH-SY5Y cells in a dose-dependent manner, and promotes apoptosis and $\mathrm{G}_{1}$ phase arrest (35). In the present study, isatin significantly reduced the distant metastasis of neuroblastoma cells in tumor-bearing mice, and synergized with CTX resulting 
in greater antimetastatic effects but minimal systemic toxicity. Mechanistically, isatin significantly decreased the circulating levels of MMP2, MMP9 and VEGF in the tumor-bearing mice, and increased the activity of the antioxidant enzymes SOD and GSH. The present study compared ISA (200 mg/kg) with the positive control drug CTX (40 $\mathrm{mg} / \mathrm{kg}$ ) and found they have similar antitumor metastasis effects, but it must be emphasized that the natural small molecule compound isatin not only has antimetastatic effects, but also protects normal cells from free radicals. Although the dosage of isatin was higher compared with the chemotherapeutic drug CTX, isatin has lower toxicity, fewer side effects and can be taken orally while the toxicity and side effects of CTX are more severe. Therefore, these data showed that the protective effect of isatin should be the focus of future research.

LSD1 is a histone demethylase that removes methyl groups from $\mathrm{H} 3 \mathrm{~K} 4$ via the flavin adenine dinucleotide-dependent oxidative reaction (37). LSD1 is an established oncogene that promotes metastasis in various cancer types, for example breast cancer, prostate cancer and acute myeloid leukemia (18-20) via epigenetic regulation of various pro-oncogenic and pro-angiogenic pathways. The tumor suppressor p53 is regulated by numerous post-translational modifications, including lysine methylation. LSD1-mediated demethylation of p53 protein represses the expression of p53 downstream targets and inhibits apoptosis (38). LSD1 can remove one (K370me1) or both (K370me2) methyl groups of p53 (19), which is reversed by isatin via LSD1 inhibition. Furthermore, isatin also upregulates p53 and its downstream protein p21, which blocks cell cycle progression in the $G_{1}$ phase by inhibiting cyclin-dependent kinases (CDK), including CDK2 and CDK4 (39). The pro-apoptotic Bax and antiapoptotic Bcl-2 and MDM 2 targets of p53 are also affected by isatin. In the present cellular experiments, it was demonstrated that isatin decreased the expression of $\mathrm{Bcl}-2$ protein, ratio of $\mathrm{Bcl}-2$ to Bax, protein expression of MDM2 and increased expression of p53, which indicated that isatin promoted apoptosis. In addition, isatin also downregulates TGF $\beta 1$, and its downstream components of the ERK/NF-kB cascade (40), which in turn inhibits LSD1 and the expression of its target genes. TGF $\beta$ signaling controls numerous cellular processes, such as proliferation, differentiation, apoptosis and migration (41), and is the central inducer of epithelial mesenchymal transition of tumor cells (42) and subsequent metastatic spread, especially that of breast cancer and prostate cancer cells to bone and lung (43). Therefore, the antimetastatic effect of isatin observed in vivo likely involves TGF $\beta 1$ inhibition. Since the molecular docking experiments of the present study suggested putative binding sites between isatin and LSD1, it was inferred that isatin can not only inhibit LSD1 via direct binding but also indirectly through the TGFß1/ERK/NF-kB pathway (Fig. 10).

Overall, isatin significantly inhibits the malignant phenotype of neuroblastoma cells and is a promising therapeutic agent against metastatic neuroblastoma either as a candidate drug or as an adjuvant of other chemotherapeutic drugs. However, the exact target of isatin was not confirmed, and there may even be multiple targets. Deeper and more overall research is still needed in this respect. In addition, as a natural small molecule lead compound, a new generation of isatin derivatives need to be developed to improve their antitumor activity.

\section{Acknowledgements}

The authors would like to thank Mr. Shaun Judge from Cure Edit for help with the writing and editing of this manuscript.

\section{Funding}

This study was supported by The National Natural Science Foundation of China (grant no. 81472542), The Focus on Research and Development Plan in Shandong Province (grant no. 2019GSF107025), The Clinical Medicine+X Project of the Medical Department of Qingdao University and Innovation Team of Qingdao, The University Medical School Youth Teacher Training Project (grant no. 600201304) and Qingdao Startup and Innovation Leader Talent Plan (grant no. 13-CX-3,201409-201709).

\section{Availability of data and materials}

The datasets used and/or analyzed during the current study are available from the corresponding author on reasonable request.

\section{Authors' contributions}

LH conceived and designed the study. LZ and YH collected and analyzed the data and analysis and wrote the final paper. YH interpretated the data. NZ, JZ, ZZ and NL collected the data and performed the experiments. JW, WZ, XL and FW analyzed the data. All authors read and approved the final manuscript.

\section{Ethics approval and consent to participate}

Not applicable.

\section{Patient consent for publication}

Not applicable.

\section{Competing interests}

The authors declare that they have no competing interests.

\section{References}

1. Vine KL, Matesic L, Locke JM, Ranson M and Skropeta D: Cytotoxic and anticancer activities of isatin and its derivatives: A comprehensive review from 2000-2008. Anticancer Agents Med Chem 9: 397-414, 2009.

2. Blažević T, Heiss EH, Atanasov AG, Breuss JM, Dirsch VM and Uhrin P: Indirubin and indirubin derivatives for counteracting proliferative diseases. Evid Based Complement Alternat Med 2015: 654098, 2015.

3. Medvedev A, Buneeva O and Glover V: Biological targets for isatin and its analogues: Implications for therapy. Biologics 1: 151-162, 2007.

4. Premanathan M, Radhakrishnan S, Kulangiappar K, Singaravelu G, Thirumalaiarasu V, Sivakumar T and Kathiresan K: Antioxidant \& anticancer activities of isatin (1H-indole-2,3-dione), isolated from the flowers of Couroupita guianensis Aubl. Indian J Med Res 136: 822-826, 2012.

5. Stafman LL and Beierle EA: Cell proliferation in neuroblastoma. Cancers (Basel) 8: 13, 2016.

6. Buhagiar A and Ayers D: Chemoresistance, cancer stem cells, and miRNA influences: The case for neuroblastoma. Anal Cell Pathol (Amst) 2015: 150634, 2015. 
7. Strother DR, London WB, Schmidt ML, Brodeur GM, Shimada H, Thorner P, Collins MH, Tagge E, Adkins S, Reynolds CP, et al: Outcome after surgery alone or with restricted use of chemotherapy for patients with low-risk neuroblastoma: Results of Children's Oncology Group study P9641. J Clin Oncol 30: 1842-1848, 2012.

8. Kreissman SG, Seeger RC, Matthay KK, London WB, Sposto R, Grupp SA, Haas-Kogan DA, Laquaglia MP, Yu AL, Diller L, et al: Purged versus non-purged peripheral blood stem-cell transplantation for high-risk neuroblastoma (COG A3973): A randomised phase 3 trial. Lancet Oncol 14: 999-1008, 2013.

9. Yu AL, Gilman AL, Ozkaynak MF, London WB, Kreissman SG, Chen HX, Smith M, Anderson B, Villablanca JG, Matthay KK, et al: Anti-GD2 antibody with GM-CSF, interleukin-2, and isotretinoin for neuroblastoma. N Engl J Med 363: 1324-1334, 2010

10. Pinto NR, Applebaum MA, Volchenboum SL, Matthay KK, London WB, Ambros PF, Nakagawara A, Berthold F, Schleiermacher G, Park JR, et al: Advances in risk classification and treatment strategies for neuroblastoma. J Clin Oncol 33: 3008-3017, 2016.

11. Hara J: Development of treatment strategies for advanced neuroblastoma. Int J Clin Oncol 17: 196-203, 2012.

12. Mazalovska M and Kouokam JC: Plant-derived lectins as potential cancer therapeutics and diagnostic tools. Biomed Res Int 2020: 1631394, 2020.

13. Han K, Zhou Y, Liu F, Guo Q, Wang P, Yang Y, Song B, Liu W, Yao Q, Teng Y and Yu P: Design, synthesis and in vitro cytotoxicity evaluation of 5-(2-carboxyethenyl)isatin derivatives as anticancer agents. Bioorg Med Chem Lett 24: 591-594, 2014.

14. Pakravan P, Kashanian S, Khodaei MM and Harding FJ: Biochemical and pharmacological characterization of isatin and its derivatives: From structure to activity. Pharmacol Rep 65: 313-335, 2013

15. Watkins P, Clow A, Glover V, Halket J, Przyborowska A and Sandler M: Isatin, regional distribution in rat brain and tissues. Neurochem Int 17: 321-323, 1990.

16. Zou P and Koh HL: Determination of indican, isatin, indirubin and indigotin in Isatis indigotica by liquid chromatography/electrospray ionization tandem mass spectrometry. Rapid Commun Mass Spectrom 21: 1239-1246, 2007.

17. Schulte JH,Lim S, Schramm A,Friedrichs N, Koster J, Versteeg R, Ora I, Pajtler K, Klein-Hitpass L, Kuhfittig-Kulle S, et al: Lysine-specific demethylase 1 is strongly expressed in poorly differentiated neuroblastoma: Implications for therapy. Cancer Res 69: 2065-2071, 2009.

18. Sakane C, Okitsu T, Wada A, Sagami H and Shidoji Y: Inhibition of lysine-specific demethylase 1 by the acyclic diterpenoid geranylgeranoic acid and its derivatives. Biochem Biophys Res Commun 444: 24-29, 2014.

19. Rotili D and Mai A: Targeting histone demethylases A new avenue for the fight against cancer. Genes Cancer 2: 663-679, 2011.

20. Wang Y, Zhang H, Chen Y, Sun Y, Yang F, Yu W, Liang J, Sun L, Yang X, Shi L, et al: LSD1 is a subunit of the NuRD complex and targets the metastasis programs in breast cancer. Cell 138: 660-672, 2009

21. Livak KJ and Schmittgen TD: Analysis of relative gene expression data using real-time quantitative PCR and the 2(-Delta Delta C(T)) method. Methods 25: 402-408, 2002.

22. Xue M, Liang H, Ji X, Liu Y and Sun T: Fucoidan prevent murine autoimmune diabetes via suppression TLR4-signaling pathways, regulation $\mathrm{DC} /$ Treg induced immune tolerance and improving gut microecology. Nutr Metab (Lond) 16: 87, 2019.

23. Soleimani A, Khazaei M, Ferns GA, Ryzhikov M, Avan A and Hassanian SM: Role of TGF- $\beta$ signaling regulatory microRNAs in the pathogenesis of colorectal cancer. J Cell Physiol: Jan 26, 2019 (Epub ahead of print)

24. Rössler J, Breit S, Havers W and Schweigerer L: Vascular endothelial growth factor expression in human neuroblastoma: Up-regulation by hypoxia. Int J Cancer 81: 113-117, 1999.
25. Tamamura R, Nagatsuka H, Siar CH, Katase N, Naito I, Sado Y and Nagai N: Comparative analysis of basal lamina type IV collagen $\alpha$ chains, matrix metalloproteinases- 2 and -9 expressions in oral dysplasia and invasive carcinoma. Acta Histochem 115 113-119, 2013.

26. Lanza C, Galeazzi V, Carboni N, De Berardinis A, De Marino L, Barile A and Giovagnoni A: Neuroblastoma image-defined risk factors in adrenal neuroblastoma: Role of radiologist. Gland Surg 8 (Suppl 3): S168-S177, 2019.

27. Orr KE and McHugh K: The new international neuroblastoma response criteria. Pediatr Radiol 49: 1433-1440, 2019.

28. Belczacka I, Latosinska A, Siwy J, Metzger J, Merseburger AS, Mischak H, Vlahou A, Frantzi M and Jankowski V: Urinary CE-MS peptide marker pattern for detection of solid tumors. Sci Rep 8: 5227, 2018.

29. Zage PE: Novel therapies for relapsed and refractory neuroblastoma. Children (Basel) 5: 148, 2018.

30. Morandi F, Frassoni F, Ponzoni M and Brignole C: Novel immunotherapeutic approaches for neuroblastoma and malignant melanoma. J Immunol Res 2018: 8097398, 2018.

31. Gencer N, Sonmez F, Demir D, Arslan O and Kucukislamoglu M: Synthesis, structure-activity relationships and biological activity of new isatin derivatives as tyrosinase inhibitors. Curr Top Med Chem 14: 1450-1462, 2014.

32. Ma Z, Hou L, Jiang Y, Chen Y and Song J: The endogenous oxindole isatin induces apoptosis of MCF7 breast cancer cells through a mitochondrial pathway. Oncol Rep 32: 2111-2117, 2014.

33. Lin H, Ju C, Zhang J, Song J, Ge Y and Wang Y: Antitumor effects of Isatin on human neuroblastoma cell line (SH-SY5Y) and the related mechanism. Eur J Pharmacol 589: 27-31, 2008.

34. Song J, Hou L, Ju C, Zhang J, Ge Y and Yue W: Isatin inhibits proliferation and induces apoptosis of SH-SY5Y neuroblastoma cells in vitro and in vivo. Eur J Pharmacol 702: 235-241, 2013

35. Xu P, Hou L, Ju C, Zhang Z, Sun W, Zhang L, Song J, Lv Y, Liu L, Chen $Z$ and Wang Y: Isatin inhibits the proliferation and invasion of SH-SY5Y neuroblastoma cells. Mol Med Rep 13: 2757-2762, 2016.

36. Zhang L, Sun W, Cao Y, Hou L and Wang X: Isatin inhibits the invasion of human neuroblastoma SH-SY5Y cells, based on microarray analysis. Mol Med Rep 20: 1700-1706, 2019.

37. Schildhaus HU, Riegel R, Hartmann W, Steiner S, Wardelmann E Merkelbach-Bruse S, Tanaka S, Sonobe H, Schüle R, Buettner R and Kirfel J: Lysine-specific demethylase 1 is highly expressed in solitary fibrous tumors, synovial sarcomas, rhabdomyosarcomas, desmoplastic small round cell tumors, and malignant peripheral nerve sheath tumors. Hum Pathol 42: 1667-1675, 2011.

38. Khandanpour C and Möröy T: Growth factor independence 1 (Gfil) as a regulator of p53 activity and a new therapeutical target for ALL. Oncotarget 4: 374-375, 2013.

39. Bandopadhyay M, Sarkar N, Datta S, Das D, Pal A, Panigrahi R, Banerjee A,Panda CK, Das C, Chakrabarti S and Chakravarty R: Hepatitis B virus X protein mediated suppression of miRNA-122 expression enhances hepatoblastoma cell proliferation through cyclin G1-p53 axis. Infect Agent Cancer 11: 40, 2016.

40. Sun W, Zhang L, Hou L, Ju C, Zhao S and Wei Y: Isatin inhibits SH-SY5Y neuroblastoma cell invasion and metastasis through MAO/HIF-1 $\alpha /$ CXCR4 signaling. Anti Cancer Drugs 28: 645-653, 2017.

41. Itatani Y, Kawada K and Sakai Y: Transforming growth factor- $\beta$ signaling pathway in colorectal cancer and its tumor microenvironment. Int J Mol Sci 20: 5822, 2019.

42. Lee HJ: The role of tripartite motif family proteins in TGF- $\beta$ signaling pathway and cancer. J Cancer Prev 23: 162-169, 2018.

43. Xie F, Ling L, van Dam H, Zhou F and Zhang L: TGF- $\beta$ signaling in cancer metastasis. Acta Biochim Biophys Sin (Shanghai) 50: 121-132, 2018. 